\title{
Helminth infracommunities of the maculated toad Amietophrynus regularis (Anura: Bufonidae) from Ismailia, Egypt
}

\author{
Mohamed Moussa Ibrahim Ibrahim* \\ Zoology Department, Faculty of Science, Suez Canal University, Ismailia, Egypt \\ Present address: Science Department, Al-Baha Teachers' College, Al-Baha University, Al-Baha, Saudi Arabia
}

\begin{abstract}
The objective of the present work was to study the helminth infracommunities of Amietophrynus (Bufo) regularis and the possible effects of intrinsic and extrinsic factors on infracommunity structure and on the infection parameters of each parasite species involved. A total of 129 A. regularis were collected from Ismailia, Egypt, over 3 seasons. Helminth infracommunities consisted of 8 helminth taxa (1 monogenean, 1 digenean, 1 cestode, 3 nematodes, and 2 acanthocephalans [1 adult and 1 cystacanth]). Aplectana macintoshii had the highest prevalence (82.94\%), mean abundance (73.74), and mean intensity (88.91) and can be considered a core species. A. macintoshii dominated in $68.99 \%$ of the infracommunities, with a high Berger-Parker index value (0.9). Only 9 toads were uninfected; the remainder harbored between 1 and 7 helminth species and 1 to 632 ind. Mean species richness and abundance were $2.13 \pm 0.13$ and $81.34 \pm 13.60$, respectively, while evenness and diversity were 0.3 and 0.44 , respectively. The results revealed that season, host sex, and age played significant roles in determining infracommunity species richness. The patterns of helminth infracommunity richness and diversity were similar to those previously observed in other amphibian hosts. This study indicated that the helminth community of $A$. regularis was depauperate.
\end{abstract}

KEY WORDS: Amietophrynus regularis $\cdot$ Helminth infracommunity $\cdot$ Body size $\cdot$ Season $\cdot$ Sex $\cdot$ Parasite load

Resale or republication not permitted without written consent of the publisher

\section{INTRODUCTION}

Studies on the helminth communities of amphibians have increased in recent years (Aho 1990, Bursey \& Goldberg 1998, Bolek \& Coggins 2000, 2001, 2003, Goldberg et al. 2002, Khidr et al. 2002, ParedesCalderon et al. 2004, Brooks et al. 2006, Hamann et al. 2006). The recent interest in amphibian parasites probably stems from the hypothesis that some parasitic species may be responsible for some amphibian declines. Johnson et al. (1999, 2001) offer compelling experimental evidence that a trematode parasite, Ribeiroia sp., is responsible for the dramatic limb deformities observed in certain amphibian populations in several areas of North America.

Most studies on the helminth community structure of amphibian hosts have been conducted in species distributed in temperate latitudes (Aho 1990, Muzzall 1991, Yoder \& Coggins 1996, McAlpine 1997, Bolek \&
Coggins 2001, 2003, Muzzall et al. 2001); therefore, it is necessary to examine more species from different localities in tropical latitudes to determine if there is general correspondence with the patterns described by Aho (1990) for amphibian helminth communities (Paredes-Calderón et al. 2004).

Amietophrynus (Bufo) regularis is widespread in savanna regions south of the Sahara and in a region stretching from Senegal through West Africa to Central Africa, and through North Africa to Egypt. This species feeds on a wide variety of vertebrates and invertebrates. However, the main components of its diet are invertebrates, including beetles, odonates, and spiders (Rödel 2000). Although there are reports of helminths of A. regularis (Khidr et al. 2002) from Egypt, no studies exist on the factors that structure the helminth infracommunities of this toad. The objective of the present work was to study the helminth infracommunities of $A$. regularis and the possible effects of intrinsic fac- 
tors (host sex, weight and age) and an extrinsic factor (season) on the structure of these infacommunities, notably on the prevalence, mean abundance and mean intensity of each parasite species involved.

\section{MATERIALS AND METHODS}

A total of 129 specimens of Amietophrynus regularis (5.1 to $7.9 \mathrm{~cm}$ in snout-vent length) were collected from Nefesha, Ismailia $\left(32^{\circ} \mathrm{N}, 30^{\circ} 30^{\prime} \mathrm{E}\right)$, in 3 seasons: winter (February 2005), spring (April 2005) and summer (July 2005). Toads were collected by hand during spring and summer. During the hibernation season (winter), specimens were collected by digging muddysand areas. The toads collected from this area can be described as semi-terrestrial. Parasitological analysis was carried out within $72 \mathrm{~h}$ of capture. Toads were killed using chloroform, and then dissected and examined for helminth parasites. The stomach, intestine, lungs, kidneys and urinary bladder were dissected and placed separately in Petri dishes containing $0.9 \%$ saline solution. The body cavity was also searched for helminths. Contents were cleaned in saline solution and examined under a dissecting microscope.

The ecological terminology follows that described by Bush et al. (1997). Analyses of helminth infracommunity structure, irrespective of site of infection, included measurements of mean number of helminths (abundance), species richness, mean diversity, and evenness (Brillouin's index). Numeric dominance was determined using the Berger-Parker dominance index. Age class was divided into 2 groups: immature refers to individuals with both forelimbs and hind limbs, which lack tails or tail stubs, and are not of breeding size; adult refers to individuals of breeding size. Sex was determined by the external appearance of mature toads (e.g. the presence of a vocal sac in males), and by dissection in the case of immature individuals. The effects of both individual and interacting factors (host sex, host age and season) on infection was statistically analyzed using the General Linear Interactive Model (GLIM) after normalization of the data by $\log _{10}(x+1)$ transformation (Crawley 1993, Wilson \& Grenfell 1997). Chi-square $\left(\chi^{2}\right)$ test was used to test for differences in prevalence, and Mann-Whitney test $(U)$ for differences in parasite abundance between host sex and age. Abundance among seasons was analyzed using the Kruskal-Wallis test. Correlations of helminth abundance with host size and weight were tested using Spearman rank correlation coefficient $\left(\mathrm{r}_{\mathrm{s}}\right)$. The degree of aggregation of the different parasite species was calculated by the Index of Dispersion $I$ (variance to mean ratio, where $I>1$ indicates overdispersed data) and the Index of Discrepancy $D$ as described by Poulin
(1993) ( $D=0$ indicates an even distribution across all hosts, and $D=1$ indicates that all parasites are aggregated in a single host). All statistical tests were performed using the software package SPSS 12.00.

\section{RESULTS}

The structure of the sampled host population by season of capture and host sex is shown in Table 1. Eight species of helminth parasites were found (Table 2) and 120 toads $(93.02 \%)$ carried at least one of these helminth species. Aplectana macintoshii was the most common (82.94\%) and Polystoma integerrimum $(6.98 \%)$ was the rarest. Two of the 8 species were rare, with low prevalence $(<11 \%)$ and low mean abundance $\left(<0.5\right.$ helminths toad $\left.^{-1}\right)$. A. macintoshii dominated in $68.99 \%$ of the infracommunities, with a high BergerParker index value (0.9). A. macintoshii had the highest prevalence $(82.94 \%)$, mean abundance (73.74) and mean intensity (88.91) and can be considered a core species. Only 9 toads were uninfected, while the remainder harbored between 1 to 7 helminth species and 1 to 632 ind. The overall mean species richness and abundance were $2.13 \pm 0.13$ and $81.34 \pm 13.60$, respectively. Cumulative species richness curves indicated that $85.34 \%$ of the helminth species found were recovered from only 38 toads. Evenness and diversity were 0.3 and 0.44 , respectively.

The distribution of infracommunity species richness (Fig. 1) showed a good fit with positive binomial $\left(\chi^{2}=\right.$ $7.2 ; \mathrm{df}=5, \mathrm{p}=0.204)$ but not with normal distribution $\left(\chi^{2}=22.88 ;\right.$ df $\left.=5, p<0.0001\right)$. Three-way ANOVA in GLIM with normal errors revealed that season, host sex and host age played significant roles in determining infracommunity species richness (Table 3, Fig. 2). There were strong significant interactions between these factors (Table 3). Species richness was significantly higher in spring and summer and lower in winter $\left(F_{2,126}=5.85, \mathrm{p}=0.004\right)$. Species richness also differed significantly between sexes $(t=4.22$; $<<0.0001)$, with male toads having higher mean species richness

Table 1. Amietophrynus regularis. Structure of the sampled host population by season of capture and host sex

\begin{tabular}{|c|c|c|c|c|c|}
\hline \multirow[t]{2}{*}{ Season } & \multicolumn{5}{|c|}{$\longrightarrow$ No. of collected toads } \\
\hline & \multicolumn{2}{|c|}{ Male - } & \multicolumn{2}{|c|}{ Female -} & Total \\
\hline Wint & 18 & 0 & 17 & 0 & 35 \\
\hline Spring & 16 & 10 & 11 & 3 & 40 \\
\hline Summer & 9 & 13 & 14 & 18 & 54 \\
\hline $\begin{array}{l}\text { Total } \\
\text { (mature }\end{array}$ & dim & $\begin{array}{l}66 \\
\text { nature) }\end{array}$ & & 63 & 129 \\
\hline
\end{tabular}


Table 2. Overall prevalence, abundance, and indices of aggregation of helminths infecting Amietophrynus regularis collected from Ismailia, Egypt. I: index of dispersion, $D$ : index of discrepancy

\begin{tabular}{|c|c|c|c|c|c|c|c|}
\hline \multirow[t]{3}{*}{ Helminth species } & \multirow[t]{3}{*}{ Microhabitat } & \multirow[t]{3}{*}{ Sex of host } & \multirow{3}{*}{$\begin{array}{c}\text { Prevalence } \\
(\%)\end{array}$} & \multicolumn{2}{|c|}{- Abundance -} & \multirow{2}{*}{\multicolumn{2}{|c|}{$\begin{array}{l}\text { Indices of } \\
\text { aggregation }\end{array}$}} \\
\hline & & & & Mean $\pm \mathrm{SE}$ & Range & & \\
\hline & & & & & & $I$ & $D$ \\
\hline \multirow[t]{3}{*}{ Aplectana macintoshii } & \multirow{3}{*}{$\begin{array}{l}\text { Small and large } \\
\text { intestine }\end{array}$} & Male & 92.42 & $120.03 \pm 21.64$ & $0-600$ & & \\
\hline & & Female & 73.01 & $25.25 \pm 12.70$ & $0-576$ & & \\
\hline & & Combined & 82.94 & $73.74 \pm 13.32$ & $0-600$ & 50.89 & 0.36 \\
\hline \multirow[t]{3}{*}{ Oxysomatium ranae } & \multirow{3}{*}{$\begin{array}{l}\text { Large } \\
\text { intestine }\end{array}$} & Male & 28.78 & $4.32 \pm 1.20$ & $0-47$ & & \\
\hline & & Female & 11.11 & $0.79 \pm 0.49$ & $0-30$ & & \\
\hline & & Combined & 20.15 & $2.60 \pm 0.67$ & $0-47$ & 22.63 & 0.85 \\
\hline \multirow[t]{3}{*}{ Rhabdias bufonis } & \multirow[t]{3}{*}{ Lung } & Male & 36.36 & $0.71 \pm 0.14$ & $0-6$ & & \\
\hline & & Female & 17.46 & $0.24 \pm 0.07$ & $0-2$ & & \\
\hline & & Combined & 37.13 & $0.48 \pm 0.08$ & $0-6$ & 1.82 & 0.78 \\
\hline \multirow[t]{3}{*}{ Polystoma integerrimum } & \multirow[t]{3}{*}{ Urinary bladder } & Male & 12.12 & $0.18 \pm 0.06$ & $0-2$ & & \\
\hline & & Female & 1.59 & $0.02 \pm 0.02$ & $0-1$ & & \\
\hline & & Combined & 6.98 & $0.10 \pm 0.03$ & $0-2$ & 1.53 & 0.92 \\
\hline \multirow[t]{3}{*}{ Pleurogenoides sitapurii } & \multirow[t]{3}{*}{ Small intestine } & Male & 12.12 & $3.11 \pm 1.26$ & $0-42$ & & \\
\hline & & Female & 6.35 & $0.19 \pm 0.09$ & $0-3$ & & \\
\hline & & Combined & 9.30 & $1.68 \pm 0.66$ & $0-42$ & 32.91 & 0.93 \\
\hline \multirow[t]{3}{*}{ Nematotaenia dispar } & \multirow{3}{*}{$\begin{array}{l}\text { Small } \\
\text { intestine }\end{array}$} & Male & 42.42 & $2.33 \pm 0.39$ & $0-10$ & & \\
\hline & & Female & 25.39 & $0.98 \pm 0.24$ & $0-6$ & & \\
\hline & & Combined & 26.36 & $1.67 \pm 0.24$ & $0-10$ & 4.34 & 0.72 \\
\hline \multirow[t]{3}{*}{ Acanthocephalus bufonis } & \multirow[t]{3}{*}{ Small intestine } & Male & 34.84 & $0.86 \pm 0.15$ & $0-4$ & & \\
\hline & & Female & 20.63 & $0.86 \pm 0.24$ & $0-6$ & & \\
\hline & & Combined & 27.91 & $0.86 \pm 0.14$ & $0-6$ & 3.01 & 0.77 \\
\hline \multirow[t]{3}{*}{ Cystacanth } & \multirow{3}{*}{$\begin{array}{l}\text { Body cavity, } \\
\text { mesenteries and } \\
\text { attached to kidney }\end{array}$} & Male & 13.63 & $0.30 \pm 0.11$ & $0-4$ & & \\
\hline & & Female & 6.35 & $0.10 \pm 0.05$ & $0-2$ & & \\
\hline & & Combined & 10.08 & $0.20 \pm 0.06$ & $0-4$ & 2.36 & 0.92 \\
\hline
\end{tabular}

(2.65) than females (1.59). Species richness did not differ between mature and immature hosts (Table $3 ; t=$ 0.33, $\mathrm{p}=0.7$ ).

Infection prevalence was higher in immature toads than in adults for Aplectana macintoshii, Oxysomatium ranae, Nematotaenia dispar, Acanthocephalus bufonis and the cystacanth. Conversely, infection prevalence was higher in adult toads for Rhabdias bufonis, Polystoma integerrimum and Pleurogenoides sitapurii (Fig. 3). Significant differences in mean abundance by host age were found only in Aplectana macintoshii, Oxysomatium ranae and Pleurogenoides sitapurii (Table 4). Immature toads had higher mean abundance

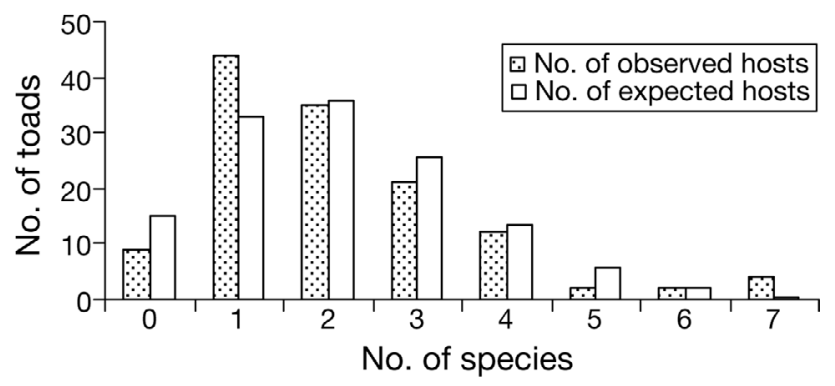

Fig. 1. Amietophrynus regularis. Frequency distribution of helminth infracommunity species richness of Aplectana macintoshii and the cystacanth when compared to adults. On the other hand, adult toads had higher mean abundance than immature individuals for Oxysomatium ranae, Rhabdias bufonis, Polystoma integerrimum, Nematotaenia dispar and Acanthocephalus bufonis. Overall helminth prevalence and mean abundance were higher in immature than in adult toads (Fig. 3).

Infection prevalence differed between sexes (Table 2), with \% prevalence in males being significantly higher than in females (Table 3). Mean abundance also differed significantly between sexes for all helminth species (Tables $3 \& 4$ ). Male toads had signif-

Table 3. Main factors affecting species richness of helminth infracommunity of maculated toad Amietophrynus regularis

\begin{tabular}{|lrrrrc|}
\hline Factors & SS & df & $\chi^{2}$ & \multicolumn{1}{c|}{$F$} & $\mathrm{p}$ \\
\hline Sex & 31.10 & 1 & 31.10 & 29.57 & $<0.0001$ \\
Age & 17.44 & 1 & 17.44 & 16.58 & $<0.0001$ \\
Season & 68.43 & 2 & 34.22 & 32.53 & $<0.00001$ \\
Sex $\times$ Age & 18.07 & 1 & 18.08 & 17.19 & $<0.00001$ \\
Sex $\times$ Season & 67.44 & 2 & 33.73 & 32.06 & $<0.00001$ \\
Age $\times$ Season & 6.16 & 1 & 6.16 & 5.85 & 0.01 \\
Sex $\times$ Age $\times$ Season & 13.55 & 1 & 13.54 & 12.88 & 0.0004 \\
Error & 125.16 & 119 & 1.05 & & \\
Total & 883 & 129 & & & \\
\hline
\end{tabular}



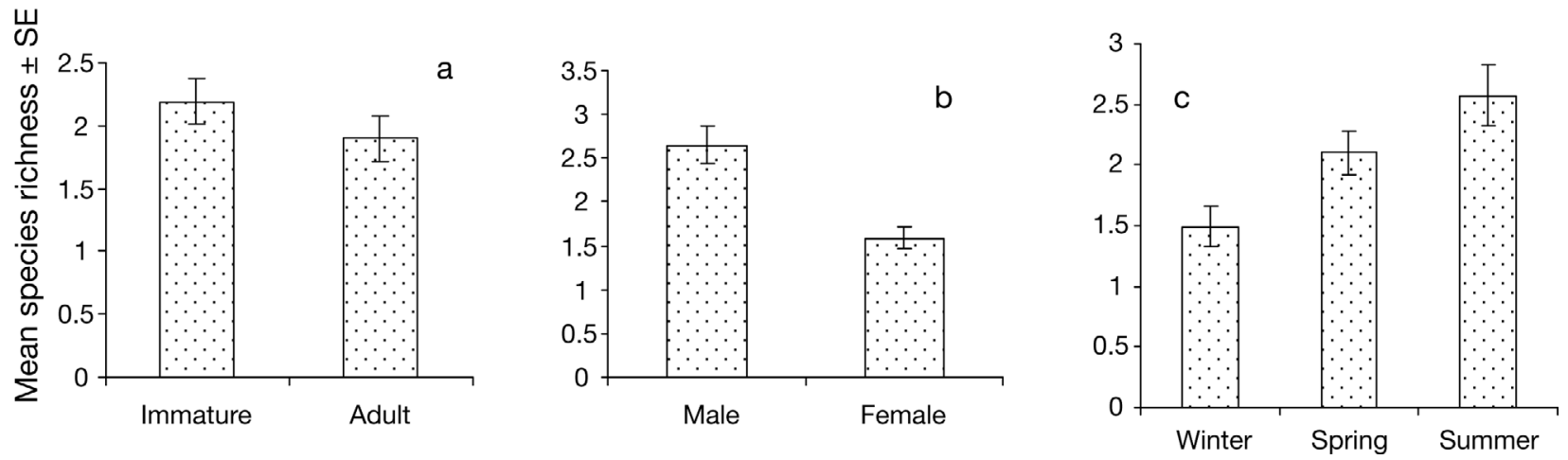

Fig. 2. Amietophrynus regularis infected by helminths. Variation of helminth infracommunity species richness in relation to (a) host age (host maturity), (b) host sex, and (c) season
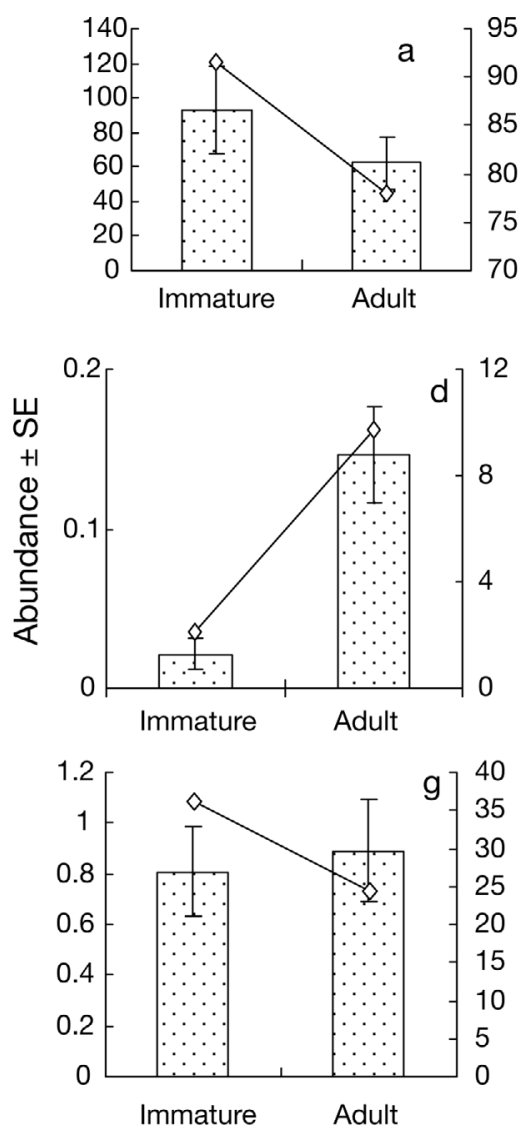
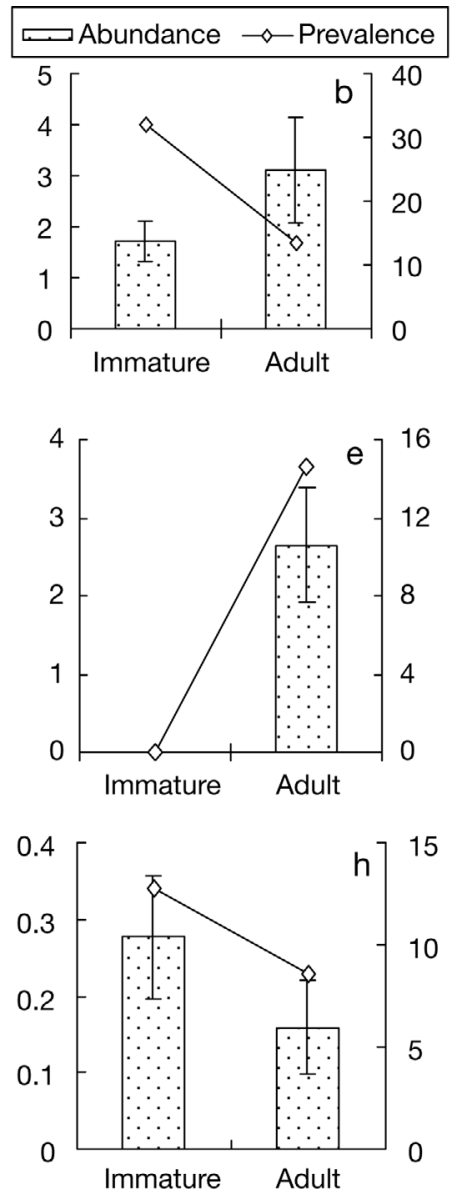
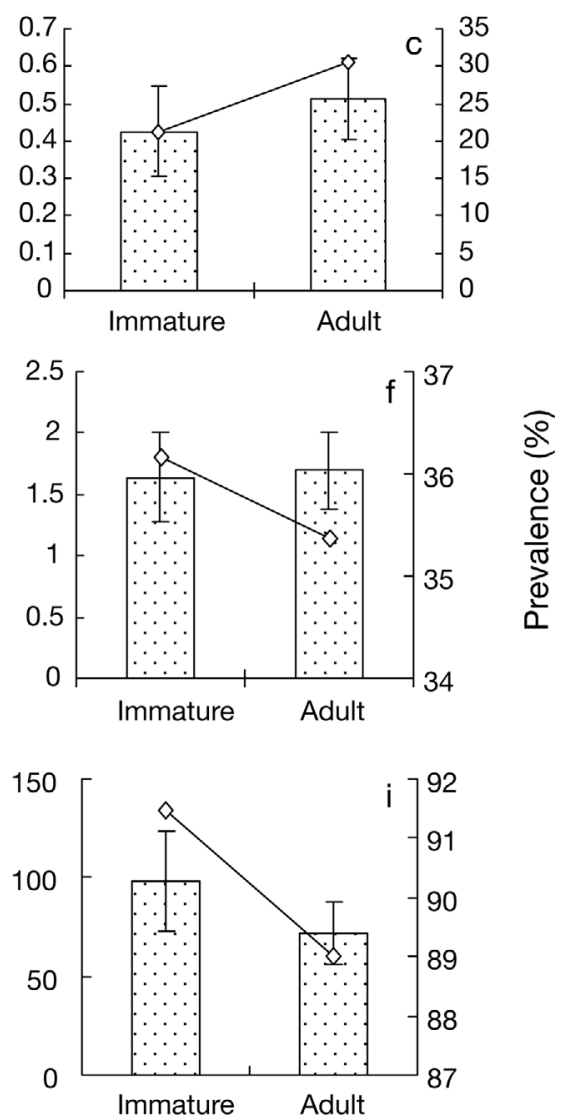

Fig. 3. Amietophrynus regularis infected by helminths. Prevalence (lines), and mean abundance (bars) \pm SE of helminths in relation to host age (maturity): (a) Aplectana macintoshii, (b) Oxysomatium ranae, (c) Rhabdias bufonis, (d) Polystoma integerrimum, (e) Pleurogenoides sitapurii, (f) Nematotaenia dispar, (g) Acanthocephalus bufonis, (h) cystacanth, and (i) total helminths combined

icantly higher mean abundance than females for all helminth species except Acanthocephalus bufonis. The overall mean abundance of helminths combined differed significantly between sexes (Table $4 ; U=852$, $\mathrm{p}<0.0001)$.
Season had significant effect on infection prevalence of Aplectana macintoshii, Oxysomatium ranae and Acanthocephalus bufonis (Fig. 4). Overall mean abundance also differed significantly among different seasons (Table $4 ; \chi^{2}=6.65, \mathrm{p}=0.04$ ), increasing from 
Table 4. Amietophrynus regularis infected by helminths. Relationship between mean abundance and host age (host maturity), host sex, season, host size (snout-vent length), and weight. $U$ : Mann-Whitney statistic $\chi^{2}$ : chi-square; $\mathrm{r}_{\mathrm{s}}$ : Spearman rank correlation coefficient

\begin{tabular}{|c|c|c|c|c|c|c|c|c|c|c|}
\hline \multirow[t]{2}{*}{ Helminth species } & \multicolumn{2}{|c|}{ Host age } & \multicolumn{2}{|c|}{ Sex } & \multicolumn{2}{|c|}{ Season } & \multicolumn{2}{|c|}{ Host size } & \multicolumn{2}{|c|}{ Host weight } \\
\hline & $U$ & $\mathrm{p}$ & $U$ & $\mathrm{p}$ & $\chi^{2}$ & $\mathrm{p}$ & $\mathrm{r}_{\mathrm{s}}$ & $\mathrm{p}$ & $\mathrm{r}_{\mathrm{s}}$ & $\mathrm{p}$ \\
\hline Aplectana macintoshii & 1359 & 0.005 & 1026 & $<0.0001$ & 10.95 & 0.004 & 0.09 & 0.27 & -0.23 & 0.008 \\
\hline Oxysomatium ranae & 1641 & 0.04 & 1663 & 0.005 & 11.33 & 0.003 & 0.02 & 0.76 & -0.24 & 0.007 \\
\hline Rhabdias bufonis & 1804 & 0.44 & 1638 & 0.008 & 0.44 & 0.80 & 0.26 & 0.003 & 0.12 & 0.19 \\
\hline Polystoma integerrimum & 1778 & 0.09 & 1858 & 0.01 & 5.06 & 0.08 & -0.07 & 0.45 & -0.13 & 0.15 \\
\hline Pleurogenoides sitapurii & 1645 & 0.006 & 1943 & 0.02 & 2.19 & 0.33 & 0.15 & 0.08 & 0.09 & 0.33 \\
\hline Nematotaenia dispar & 1915 & 0.94 & 1626 & 0.013 & 3.65 & 0.16 & 0.09 & 0.23 & 0.069 & 0.43 \\
\hline Acanthocephalus bufonis & 1763 & 0.31 & 1812 & 0.11 & 8.95 & 0.01 & -0.08 & 0.36 & 0.116 & 0.19 \\
\hline Cystacanth & 1845 & 0.44 & 1821 & 0.015 & 1.27 & 0.52 & -0.12 & 0.15 & 0.07 & 0.39 \\
\hline Total helminths & 1605 & 0.11 & 852 & $<0.0001$ & 6.65 & 0.04 & 0.006 & 0.95 & -0.124 & 0.16 \\
\hline
\end{tabular}
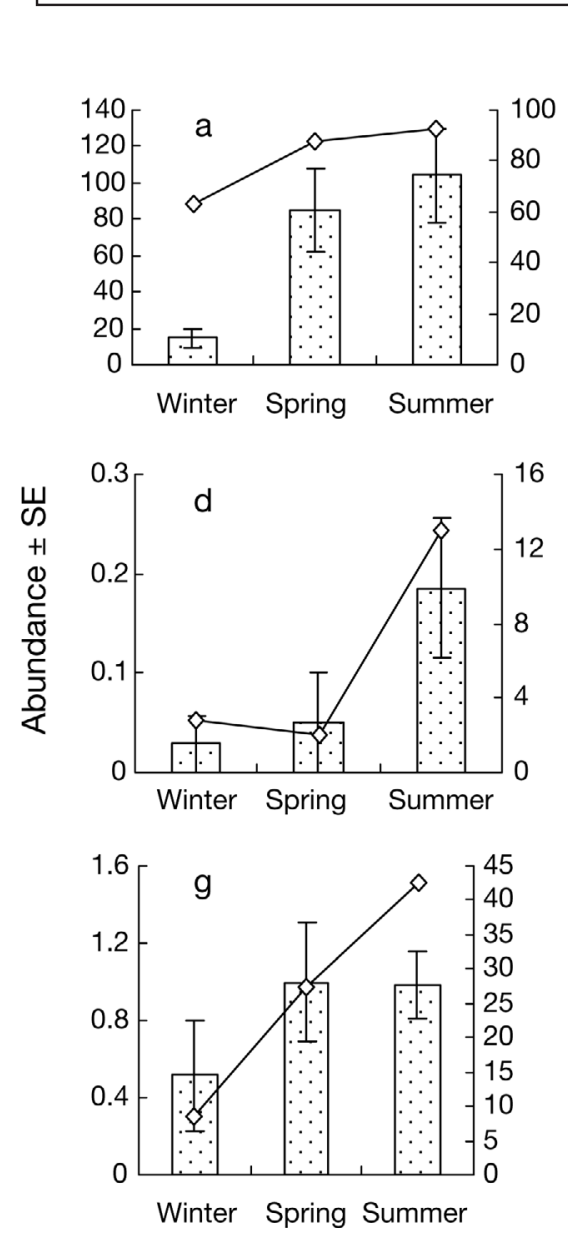
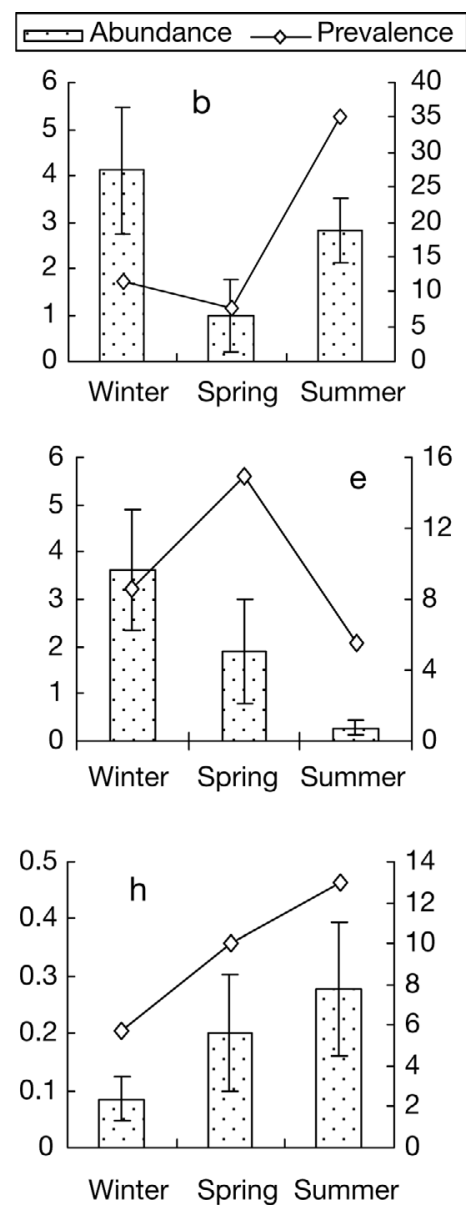
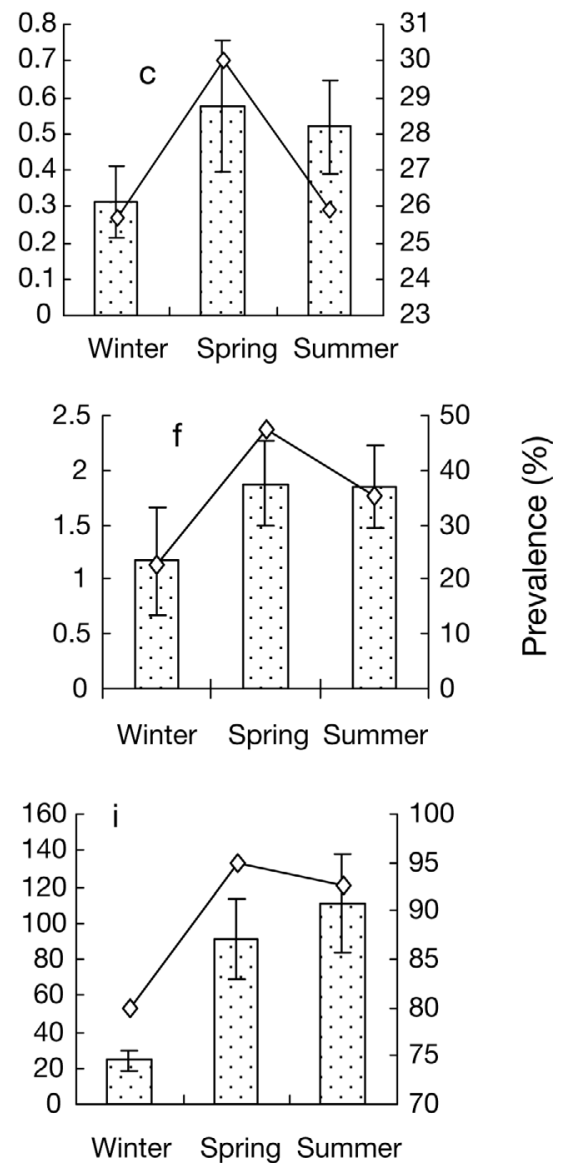

Fig. 4. Amietophrynus regularis infected by helminths. Seasonal variation in prevalence (lines), and mean abundance (bars) $\pm \mathrm{SE}$ of helminths: (a) Aplectana macintoshii, (b) Oxysomatium ranae, (c) Rhabdias bufonis, (d) Polystoma integerrimum, (e) Pleurogenoides sitapurii, (f) Nematotaenia dispar, (g) Acanthocephalus bufonis, (h) cystacanth, and (i) total helminths combine

24.22 ind. in winter to 110.87 ind. in summer (Fig. 4). Of the 8 parasites, Aplectana macintoshii, Oxysomatium ranae and Acanthocephalus bufonis showed significant difference in mean abundance among seasons (Table 4, Fig. 4). The frequency distribution of helminth abundance showed that they were over- dispersed, with $I>1$ (Table 2). The mean intensity differed significantly among different seasons in $O x y$ somatium ranae, Rhabdias bufonis, Pleurogenoides sitapurii and Acanthocephalus bufonis.

Three-way ANOVA in GLIM after data normalization (by $\log _{10}(x+1)$ transformation) showed that sex 
Table 5. Test of interaction (general linear model) between factors affecting mean abundance of helminth infracommunity of the maculated toad Amietophrynus regularis. Values of $p<0.05$ are significant

\begin{tabular}{|c|c|c|c|c|c|}
\hline $\begin{array}{l}\text { Helminth species } \\
\text { Factor considered }\end{array}$ & SS & $\mathrm{df}$ & $\chi^{2}$ & $F$ & $\mathrm{p}$ \\
\hline \multicolumn{6}{|l|}{ Aplectana macintoshii } \\
\hline Sex & 6.88 & 1 & 6.88 & 17.82 & $<0.0001$ \\
\hline Age & 0.97 & 1 & 0.97 & 2.51 & 0.11 \\
\hline Season & 8.67 & 2 & 4.33 & 11.23 & $<0.0001$ \\
\hline Sex $\times$ Age & 6.07 & 1 & 6.07 & 15.73 & 0.0001 \\
\hline Sex $\times$ Season & 7.11 & 2 & 3.55 & 9.21 & 0.0001 \\
\hline Age $\times$ Season & 12.20 & 1 & 12.20 & 31.61 & $<0.0001$ \\
\hline \multicolumn{6}{|l|}{ Oxysomatium ranae } \\
\hline Sex & 1.40 & 1 & 1.40 & 10.98 & 0.001 \\
\hline Season & 1.93 & 2 & 0.96 & 7.57 & 0.001 \\
\hline Sex $\times$ Age & 0.82 & 1 & 0.82 & 6.45 & 0.01 \\
\hline Sex $\times$ Season & 3.16 & 2 & 1.58 & 12.37 & $<0.0001$ \\
\hline Age $\times$ Season & 0.50 & 1 & 0.50 & 3.92 & 0.05 \\
\hline Sex $\times$ Age $\times$ Season & 0.64 & 1 & 0.63 & 4.97 & 0.02 \\
\hline \multicolumn{6}{|l|}{ Rhabdias bufonis } \\
\hline Sex & 0.32 & 1 & 0.32 & 10.55 & 0.001 \\
\hline Age & 0.20 & 1 & 0.20 & 6.74 & 0.01 \\
\hline Season & 0.26 & 2 & 0.13 & 4.37 & 0.01 \\
\hline Sex $\times$ Season & 0.72 & 2 & 0.36 & 11.92 & $<0.0001$ \\
\hline Sex $\times$ Age $\times$ Season & 0.12 & 1 & 0.12 & 3.94 & 0.04 \\
\hline \multicolumn{6}{|c|}{ Polystoma integerrimum } \\
\hline Sex & 0.08 & 1 & 0.08 & 22.64 & $<0.0001$ \\
\hline Age & 0.17 & 1 & 0.17 & 47.35 & $<0.0001$ \\
\hline Season & 0.29 & 2 & 0.15 & 40.98 & $<0.0001$ \\
\hline Sex $\times$ Age & 0.20 & 1 & 0.20 & 55.55 & $<0.0001$ \\
\hline Sex $\times$ Season & 0.27 & 2 & 0.14 & 37.81 & $<0.0001$ \\
\hline Age $\times$ Season & 0.12 & 1 & 0.12 & 34.34 & $<0.0001$ \\
\hline Sex $\times$ Age $\times$ Season & 0.15 & 1 & 0.15 & 41.38 & $<0.0001$ \\
\hline \multicolumn{6}{|c|}{ Pleurogenoides sitapurii } \\
\hline Age & 0.67 & 1 & 0.67 & 6.41 & 0.01 \\
\hline \multicolumn{6}{|l|}{ Nematotaenia dispar } \\
\hline Season & 0.94 & 2 & 0.47 & 4.30 & 0.01 \\
\hline Sex $\times$ Age & 1.09 & 1 & 1.09 & 9.98 & 0.002 \\
\hline Age $\times$ Season & 2.05 & 1 & 2.05 & 18.74 & $<0.0001$ \\
\hline \multicolumn{6}{|c|}{ Acanthocephalus bufonis } \\
\hline Age & 0.35 & 1 & 0.35 & 6.53 & 0.01 \\
\hline Season & 0.92 & 2 & 0.46 & 8.59 & 0.001 \\
\hline Sex $\times$ Season & 1.36 & 2 & 0.68 & 12.71 & $<0.0001$ \\
\hline Age $\times$ Season & 0.28 & 1 & 0.28 & 5.20 & 0.02 \\
\hline Sex $\times$ Age $\times$ Season & 0.22 & 1 & 0.22 & 4.08 & 0.04 \\
\hline \multicolumn{6}{|l|}{ Total helminths } \\
\hline Sex & 6.61 & 1 & 6.61 & 20.64 & 0.0001 \\
\hline Season & 5.99 & 2 & 2.99 & 9.37 & 0.0001 \\
\hline Sex $\times$ Age & 4.40 & 1 & 4.40 & 13.76 & 0.0003 \\
\hline Sex $\times$ Season & 7.69 & 2 & 3.85 & 12.02 & 0.0001 \\
\hline Age $\times$ Season & 7.88 & 1 & 7.88 & 24.64 & 0.0001 \\
\hline
\end{tabular}

weight and mean intensity of Acanthocephalus bufonis $\left(\mathrm{r}_{\mathrm{s}}=0.48, \mathrm{p}=0.003\right)$. On the other hand, a negative correlation was found between weight and mean abundance of Aplectana macintoshii $\left(\mathrm{r}_{\mathrm{s}}=-0.23, \mathrm{p}=0.008\right)$ and Oxysomatium ranae $\left(\mathrm{r}_{\mathrm{s}}=-0.24, \mathrm{p}=\right.$ 0.007 ) and mean intensity of Rhabdias bufonis $\left(\mathrm{r}_{\mathrm{s}}=-0.33, \mathrm{p}=0.04\right)$.

\section{DISCUSSION}

Helminth communities of amphibians are generally regarded as depauperate and isolationist (Aho 1990, Muzzall 1991, Yoder \& Coggins 1996, Bolek \& Coggins 2001, 2003). However, Hamann et al. (2006) found no fixed pattern, i.e. helminth communities were at an intermediate point between isolationist and interactive. In this study, helminth infracommunities of Amietophrynus regularis show low diversity and species richness, and can thus be considered depauperate. The characteristics of the infracommunities studied herein correspond with the patterns described for helminth communities of amphibians by Aho (1990), particularly in the sense that they are depauperate, and are highly variable. Mean species richness in this study was 2.13 as compared with 0.8 in temperate regions (Aho 1990). Mean species richness recorded in other amphibian species in tropical regions were 3.49 (Paredes-Calderón et al. 2004) and 2.40 (Hamann et al. 2006). Aho (1990) identified 2 interacting factors responsible for the observed patterns in amphibians: host vagility and energetic demands of poikilothermy. He suggested that reduced host vagility would restrict exposure to many helminth species, and that the low energetic demands of poikilothermy would reduce consumption of potential intermediate hosts.

and season had significant main effects on total parasite abundance (Table 5). The main effect of age was also significant except in Oxysomatium ranae and Nematotaenia dispar. There were also interactions between host age, sex and season in some of the helminth fauna. A positive correlation was found between
Our results are in agreement with Aho (1990), who noted the number of nematode species and individuals to vary between host species, but to frequently dominate the helminth community composition. Amietophrynus regularis infracommunities were also dominated by nematodes in both number and species 
composition (3 species of nematode and 9910 ind.). The majority of parasite communities of bufonid amphibians show a higher number of nematode species (Goldberg \& Bursey 1991, 1992, Goldberg et al. 1995, Bolek \& Coggins 2000, 2003, Luque et al. 2005) than trematodes, as observed for several ranid hosts (McAlpine 1997, Bolek \& Coggins 2000, Muzzall et al. 2001, Paredes-Calderón et al. 2004). Terrestrial toads predominantly feed on ants, beetles and other terrestrial invertebrates, thereby preventing them from becoming infected with several species of trematodes which commonly infect aquatic amphibians such as ranids (Luque et al. 2005).

Results showing that male toads had higher mean species richness (2.65) than females (1.59) are in agreement with those of Vashetko \& Siddikov (1999), who reported richer helminth fauna in male Amietophrynus viridis than in females.

The overall helminth prevalence and mean abundance were higher in immature than in adult toads contrary to the findings of Muzzall (1991) and McAlpine (1997) on various ranid species. These differences could be explained by ontogenetic changes in the host diet and by behavior; both characteristics have important roles in parasite recruitment and may be correlated with the host's body size.

The present study showed that male toads had higher prevalence and mean abundance of parasites than females for all helminth species except Acanthocephalus bufonis. This result is in agreement with Khidr et al. (2002) who found that male Bufo regularis have higher infection rate than females. Testosterone has been shown to have a negative impact on immune response in some vertebrates (Casto et al. 2001, Hughes \& Randolph 2001). There are at least 2 potential pathways in which increased steroid levels can influence parasite load in free-ranging animals. First, testosterone may increase movement, display rates and aggression, which can lead to higher exposure to parasites (Klein 2000). Second, testosterone may increase susceptibility to infection or infestation by directly lowering the immunocompetence of the individual via suppression of the immune system (Hillgarth \& Wingfield 1997).

The higher overall prevalence of parasites in spring, and the higher mean combined abundance in summer agree with the previous findings of Wetzel \& Esch (1996), Khidr et al. (2002), and Hamann et al. (2006). The ectothermic condition of amphibians limits helminth recruitment potential and community development in winter by affecting both feeding rates and foraging behavior (Aho 1990, Bolek \& Coggins 2000, Paredes-Calderón et al. 2004). Seasonal variation in the prevalence and abundance of helminths may be due to a combination of factors, including variation in ingestion rates of infective stages, breeding period, age, sex and foraging activity of hosts.

This study focused on the contribution of one extrinsic (season) and 2 intrinsic factors (age and sex) in attempting to explain variations in prevalence and mean abundance of helminth infracommunities of Amietophrynus regularis. These factors interact in various ways to shape the infracommunity structure in a given habitat at a specific time. Apparently, the main forces determining infracommunity structure are ectothermy (as a regulator of the ingestion rate), and the feeding habits of the hosts, because most of the helminth taxa enter the host by ingestion of intermediate hosts.

In conclusion, more extensive studies of amphibian helminth communities and incorporating them into a phylogenetic context are required to make more robust predictions about patterns and processes in these host-parasite systems.

\section{LITERATURE CITED}

Aho JM (1990) Helminth communities of amphibians and reptiles: comparative approaches to understanding patterns and processes. In: Esch GW, Bush AO, Aho JM (eds) Parasite communities: patterns and processes. Chapman \& Hall, London, p 157-196

Bolek MG, Coggins JR (2000) Seasonal occurrence and community structure of helminth parasites from the eastern American toad Bufo americanus americanus from southeastern Wisconsin, USA. Comp Parasitol 67:202-209

Bolek MG, Coggins JR (2001) Seasonal occurrence and community structure of helminth parasites in green frogs, Rana clamitans melanota, from southeastern Wisconsin, USA. Comp Parasitol 68:164-172

Bolek MG, Coggins JR (2003) Helminth community structure of sympatric Eastern American toad Bufo americanus americanus, northern leopard frog Rana pipiens, and blue-spotted salamander Ambystoma laterale from southeastern Wisconsin. J Parasitol 89:673-680

Brooks DR, Leon-Regagnon V, McLennan DA, Zelmer D (2006) Ecological fitting as a determinant of the community structure of platyhelminth parasites of anurans. Ecology 87 (Suppl):76-85

Bursey CR, Goldberg SR (1998) Helminths of the Canadian toad Bufo hemiophrys (Amphibia: Anura) from Alberta, Canada. J Parasitol 84:617-618

Bush AO, Lafferty KD, Lotz JM, Shostak AW (1997) Parasitology meets ecology on its own terms: Margolis et al. revisited. J Parasitol 83: 575-583

Casto JM, Nolan JRV, Ketterson ED (2001) Steroid hormone and immune function: experimental studies in wild and captive dark-eyed juncos. Am Nat 157:408-420

Crawley MT 1993. GLIM for ecologists. Blackwell Scientific Press, Oxford

Goldberg SR, Bursey CR (1991) Helminths of three toads, Bufo alvarius, Bufo cognatus (Bufonidae), and Scaphiopus couchii (Pelobatidae), from Southern Arizona. J Helminthol Soc Wash 58:142-146

Goldberg SR, Bursey CR (1992) Helminths of the marine toad Bufo marinus (Anura: Bufonidae) from American Samoa. J Helminthol Soc Wash 59:131-133 
Goldberg SR, Bursey CR, Tawil R (1995) Helminths of an introduced population of the giant toad Bufo marinus (Anura: Bufonidae) from Bermuda. J Helminthol Soc Wash 62:64-67

Goldberg SR, Bursey CR, Salgado-Maldonado G, Báezvale R, Cañeda-Guzmán C (2002) Helminth parasites of six species of anurans from Los Tuxtlas and Catemaco Lake, Veracruz, Mexico. Southwest Nat 47:293-299

- Hamann MI, González CE, Kehr AI (2006) Helminth community structure of the oven frog Leptodactylus latinasus (Anura, Leptodactylidae) from Corrientes, Argentina. Acta Parasitol 51:294-299

Hillgarth N, Wingfield JC (1997) Parasite-mediated sexual selection: endocrine aspects. In: Clayton DH, Moore J (eds) Host-parasite evolution. General principles and avian models. Oxford University Press, New York, p 78-104

Hughes VL, Randolph SE (2001) Testosterone depresses innate and acquired resistance to ticks in natural rodent hosts: a force for aggregated distributions of parasites. J Parasitol 87:49-54

Johnson PTJ, Lunde KB, Ritchie EG, Launer AE (1999) The effect of trematode infection on amphibian limb development and survivorship. Science 284:802-804

> Johnson PTJ, Lunde KB, Haight RW, Bowerman J, Blaustein AR (2001) Ribeiroia ondatrae (Trematoda: Digenea) infection induces severe limb malformations in western toads (Amietophrynus boreas). Can J Zool 79:370-379

Khidr AA, Abou Samak OA, Abd El-Manem OA (2002) Intensity of some intestinal parasites infecting the maculated toad Bufo regularis in Damietta governorate, Egypt. J Egypt Ger Soc Zool (38D):31-46

Klein SL (2000) The effects of hormones on sex differences in infection: from genes to behavior. Neurosci Biobehav Rev 24:627-638

Luque JL, Martins AN, Tavares LER (2005) Community structure of metazoan parasites of the yellow Cururu toad Bufo

Editorial responsibility: Alex Hyatt, Geelong, Victoria, Australia ictericus (Anura, Bufonidae) from Rio de Janeiro, Brazil. Acta Parasitol 50:215-220

McAlpine FD (1997) Helminth communities in bullfrogs (Rana catesbeiana), green frogs (Rana clamitans), and leopard frogs (Rana pipiens) from New Brunswick, Canada. Can J Zool 75:1883-1890

Muzzall PM (1991) Helminth infracommunities of the frogs Rana catesbeiana and Rana clamitans from Turkey Marsh, Michigan. J Parasitol 77:366-371

Muzzall PM, Gillilland MG, Summer CS, Mehne CJ (2001) Helminth communities of green frogs, Rana clamitans Latreille, from southwestern Michigan. J Parasitol 87: 962-968

Paredes-Calderón L, Leon-Regagnon V, Garcia-Prieto L (2004) Helminth infracommunities of Rana vaillanti brocchi (Anura: Ranidae) in Los Tuxtlas, Veracruz, Mexico. J Parasitol 90:692-696

Poulin R (1993) The disparity between observed and uniform distributions: a new look at parasite aggregation. Int J Parasitol 23:937-944

Rödel MO (2000) Herpetofauna of West Africa, Vol I. Amphibians of the West African savanna. Edition Chimaira, Frankfurt

Vashetko EV, Siddikov H (1999) The effect of the ecology of toads on the distribution of helminths. Turk J Zool 23: $107-110$

Wetzel EJ, Esch GW (1996) Seasonal population dynamics of Halipegus occidualis and Halipegus eccentricus (Digenea: Hemiuridae) in their amphibian host Rana clamitans. J Parasitol 82:414-422

Wilson K, Grenfell BT (1997) Generalized linear modeling for parasitologists. Parasitol Today 13:33-38

Yoder RH, Coggins JR (1996) Helminth communities in the northern spring peeper Pseudacris c. crucifer Wied, and the wood frog Rana sylvatica Le Conte from Southeastern Wisconsin. J Helminthol Soc Wash 63:211-214

Submitted: October 17, 2007; Accepted: July 6, 2008 Proofs received from author(s): September 19, 2008 